Отже, застосування інтерактивних методів навчання на заняттях 3 іноземної мови можна розглядати як педагогічну умову, що сприятиме набуттю майбутніми вчителями необхідних умінь та навичок комунікативної толерантності. 3 огляду на зазначене перспективою подальшого дослідження $\epsilon$ розроблення змісту позааудиторних інтерактивних занять задля підготовки студентів до формування толерантності в учнів основної школи в майбутній професійній діяльності.

\title{
Література
}

1. Бондаренко М. П. Організація і виховання студентського колективу / М. П. Бондаренко. - К. : Вища школа, 1979. - 69 с. 2. Вахрушева Т. Ю. Теоретичні аспекти активних методів навчання [Електронний ресурс]. - Режим доступу: http://www.nbuv.gov.ua/portal/Soc_Gum/PPMB/texts/2008-03/08vtyaml.pd

3. Свтух М. Б. Сучасні тенденції професійної підготовки вчителя / М. Б. Свтух // Психолого-педагогічні основи гуманізації навчально-виховного процесу в школі та вузі: зб. наук. праць. - Рівне : Волинські обереги, 2002. - Вип. 3. - С. 170-175. 4. Исмагилова 3. А. Воспитание толерантности у студентов педагогического вуза в процессе изучения иностранного язика: автореф. дис. на соискание ученой степени канд. пед. наук: специальность 13.00.01 «Общая педагогика, история педагогики и образования» / 3. А. Исмагилова. - Казань, 2007. - 20 с. 5. Пащенко М. І. Активні методи навчання у підготовці майбутніх учителів[Електронний ресурс].- Режим доступу: http://eprints.zu.ua/2142/1/3.pdf.6. Педагогика и психология высшей школы / под ред. С. И. Самыгина. - Ростов-н/Д. : Феникс, 1998. - 526 с. 7. Пометун О. Енциклопедія інтерактивного навчання/ О. Пометун. - К. : АСК, 2007.- 144 с. 8. Хлєбнікова Т. М. Ділова гра як метод активного навчання педагога:[навч.-метод. посіб. для викл., директорів шкіл, керівн. РУО]/ Т. М. Хлєбнікова. - Х. : ВГ «Основа», 2003. - 80 с.

УДК 37.012:[378:37.011.3]

Світлана Мантуленко

\section{СИСТЕМНИЙ МОНІТОРИНГ У ФОРМУВАННІ ГОТОВНОСТІ МАЙБУТНІХ УЧИТЕЛІВ ГЕОГРАФЇ̈ ДО ПРОФІЛЬНОГО НАВЧАННЯ СТАРШОКЛАСНИКІВ ЯК НЕОБХІДНА УМОВА ЕФЕКТИВНОСТІ ЦЬОГО ПРОЦЕСУ}

Мантуленко С. В. Системний моніторинг у формуванні готовності майбутніх учителів географії до профільного навчання старшокласників як необхідна умова ефективності цього процесу.

У статті здійснено аналіз наукових підходів до визначення сутності проблеми моніторингу в освіті, теоретично обгрунтовано механізм здійснення системного моніторингу у формуванні готовності майбутніх учителів географії до профільного навчання старшокласників як важливої умови ефективності цього процесу.

Ключові слова:моніторинг, освітній моніторинг, моніторинг професійного розвитку, системний моніторинг, контроль.

Мантуленко С. В. Системный мониторинг в формировании готовности будущих учителей географии к профильному обучению старшеклассников как необходимое условие эффективности этого процесса.

В статье осуществлён анализ научных подходов к определению сущности проблемы мониторинга в образовании, теоретически обосновано осуществление системного мониторинга в формировании готовности будущих учителей географии к профильному обучению старшеклассников как необходимое условие эффективности 
этого процесса.

Ключевые слова: мониторинг, образовательный мониторинг, мониторинг профессионального развития, системный мониторинг, контроль.

Mantulenko S. V. Systematic monitoring in forming the availability of future geography teachersfor core (profile) education high school students as a necessary condition for the effectiveness of this process.

The analysis of scientific approaches for the determination the problem of monitoring in education, the theoretical justification of the systematic monitoring in forming the availability of future geography teachers for core (profile) education high school students as a necessary condition for the effectiveness of this process are realized in the article.

Key words:monitoring, monitoring education, monitoring professional development, system monitoring, and control.

Процес формування готовності майбутнього вчителя географії до профільного навчання старшокласників досить складний, довготривалий, на який впливає низка умов та чинників. 3 одного боку, він детермінований загальними засадами професійної підготовки вчителя, а 3 іншого - специфікою профільного навчання як особливого освітнього середовища, яке висуває до професійної підготовки вчителя окремі вимоги.

Важливим аспектом професійно-педагогічної підготовки в умовах сьогодення, на нашу думку, є прогностичний підхід, що органічно поєднує контроль, прогноз і корекцію, завдяки чому забезпечується ефективне дослідження та оцінювання підготовки майбутнього вчителя.

Кінцевим продуктом освітньої системи ВНЗ є рівень готовності випускників вищої школи до відповідної діяльності, цей рівень для певного випуску є тією об'єктивною реальністю, яку можна лише виміряти та оцінити (при застосуванні об'єктивних методів). 3 іншого боку, отримані дані можна використати також для оцінки якості освітнього процесу, що створює можливості корекції його відповідно до визначеного еталону майбутньої діяльності. Дані оцінки передбачають, крім результативних, і процесуальні компоненти та показники змісту навчання, його форм та методів, що у свою чергу надасть можливість ефективно управляти цим процесом. Саме тому об'єктивною необхідністю отримання такої інформації $є$ застосування системи моніторингу та контролю процесу підготовки педагогічних кадрів, виявлення рівня їх готовності до майбутньої професійно-педагогічної діяльності.

Метою статті є: здійснення аналізу наукових підходів до визначення сутності проблеми моніторингу в освіті; виявлення його можливостей та функцій у системі професійної підготовки майбутніх учителів; теоретичне обгрунтування системного моніторингу у формуванні готовності майбутніх учителів географії до профільного навчання старшокласників як важливої умови ефективності цього процесу.

На сучасному етапі все частіше в галузі освіти застосовується поняття «моніторинг». Проблемі моніторингу якості освіти присвячені роботи Т. Боровкової, Г. Сльнікової,О. Локшиної, Т. Лукіної, О. Ляшенка, О. Майорова, Д. Матроса, Н. Мельникової, В. Мокшеєва, І. Морева, Д. Полєва, М. Поташника, В. Приходька, Дж. Уілмса та ін. Особливості моніторингу якості діяльності загальноосвітнього навчального закладу розглядалися в дослідженнях С. Бабінець, О. Дахіна, Г. Єльникової, В. Кальней, С. Подмазіна, Г. Полякової, С. Шишова.

У психолого-педагогічній літературі є багато напрацювань щодо висвітлення загальних підходів до проблеми моніторингу в освіті. Досить грунтовно це питання 
досліджено О. Майоровим. У його роботі [2] розглянуто історію становлення моніторингу, побудована розгорнута класифікація видів моніторингу за різними ознаками, сформульовані вимоги до інформації зворотного зв'язку, надається огляд різних таксономій, що є підгрунтям для побудови систем моніторингу, визначені його функції, подано загальне визначення поняття «моніторинг в освіті». Натомість у сучасній українській педагогічній науці недостатньо приділяється уваги висвітленню цього питання, не обгрунтовані підходи щодо ефективного функціонування моніторингу в системі професійної підготовки майбутніх учителів. Невизначені чіткі критерії здійснення системного моніторингу у формуванні готовності майбутніх учителів географії до профільного навчання старшокласників, що $\epsilon$ необхідною умовою ефективності цього процесу.

Виходячи із сучасних тенденцій розвитку теорії і практики освіти, варто зазначити про відсутність єдиних підходів до трактування сутності поняття «моніторинг». Одні науковці і практики (П. Анісімов, В. Зуєв, О. Майоров, Л. Шибаєва) трактують моніторинг як засіб удосконалення системи інформаційного забезпечення управління освітою, інші (А. Галаган, А. Савельєв) - підвищення ефективності стратегічного планування розвитку середньої і вищої професійної освіти [2, с. 12]. А. Орлов розглядає моніторинг у контексті підвищення якості управлінських рішень під час здійснення педагогічних інновацій [1, с. 224]. Дещо іншої точки зору дотримується дослідниця М. Чандра, визначаючи моніторинг «як комплексну систему вимірювання результативної та процесуальної сторін якості навчального процесу, що характеризується цілісною сукупністю системних властивостей та забезпечує отримання різнобічної інформації про якість навчального процесу вищого навчального закладу від усіх зацікавлених сторін [4, с. 56].

Незважаючи на різні підходи у тлумаченні сутності цього поняття, всі автори одностайні в тому, що моніторинг сприяє вдосконаленню інформаційного забезпечення управління освітою, спрямований на виявлення й регуляцію деструктивних упливів зовнішніх i внутрішніх чинників освітньої системи i спрямований на досягнення бажаних результатів іiі розвитку. Тому цілком закономірно, можна стверджувати, що моніторинг - це інформаційно-регулятивний супровід розвитку будь-якої системи.

Педагогічний моніторинг тлумачать як форму організації, збору, зберігання, оброблення та розповсюдження інформації про діяльність педагогічної системи, що забезпечує стеження за іiі станом, а також дає можливість прогнозу розвитку педагогічної системи [3, с. 78]. Відповідно, під моніторингом професійного розвитку майбутніх учителів ми розуміємо процес безперервного відстеження професійно важливих особистісних характеристик, що детермінують професійне становлення студента, а також параметри оцінювання їх професійного розвитку.

Залежно від обраного об’єкта моніторингу визначається вид моніторингу, постановка специфічних цілей і завдань, пов'язаних 3 їх реалізацією на практиці. Моніторинг реалізується за двома основними напрямками. По-перше, відстежуються параметри діяльності, процесуальні характеристики, оскільки ці дані є найбільш інформативними та оперативними порівняно з результативними. По-друге, здійснюється спостереження, даються оцінка та прогноз зміни стану об'єкта моніторингу.

Вихідним положенням моніторингу $є$ його зв'язок 3 цілями навчання, які зазвичай передбачені навчальним планом, тобто моніторинг пов'язаний 3 оцінкою реалізації цілей i планів, порівняння фактичного рівня підготовки 3 планами. Головним завданням моніторингу є зменшення різниці між ними, виявлення та 
усунення негативних чинників впливу на них [3, с. 94].

Виходячи зі специфіки нашого дослідження та тих завдань, які ми перед собою ставимо, уважаємо за необхідне розглядати моніторинг з позиції системного підходу.

Системний підхід - це цілісний процес, у якому тісно переплітаються впливи і взаємовпливи всіх структурних компонентів цілісної системи моніторингу якості освіти. Він дає змогу розглядати результативність моніторингу не як просту суму складників упливу, а як сумарний «системний ефект» (не лише вплив «якості» педагогічного колективу, інформаційних, матеріальних і технологічних ресурсів тощо, а сукупності якостей, які визначають оптимальність усього процесу) [4, с. 45]. При цьому слід також зауважити, що під час порівняння понять «моніторинг» i «контроль» головною їх відмінністю $є$ те, що контроль оперує «чистими» даними, отриманими у процесі його проведення, а моніторинг використовує динаміку отриманих даних.

Отже, важливою умовою оптимізації та інтенсифікації процесу формування досліджуваної готовності є здійснення системного моніторингу та контролю процесу формування готовності майбутніх учителів географії до профільного навчання старшокласників на всіх етапах її становлення.

Це надасть об'єктивну інформацію про стан підготовки майбутніх учителів географії до профільного навчання старшокласників, рівня їх готовності до означеної діяльності, сприятиме ефективному управлінню цим процесом, виявленню проблем та недоліків. Отримані дані створюють можливість внесення коректив щодо вдосконалення відповідної підготовки, прогнозування очікуваних результатів, передбачення перспектив розвитку. Також слід зауважити, що система моніторингу та контролю процесу формування досліджуваної готовності спонукатиме студентів до здійснення самооцінки та рефлексії власних досягнень у цьому напрямку та формуватиме стійку потребу подальшого самовдосконалення, підвищення рівня власної готовності до праці в умовах профільного навчання.

Системний моніторинг і контроль за процесом формування готовності майбутніх учителів географії до діяльності в умовах профільного навчання передбачає: розроблення і застосування діагностичних методик для вивчення рівня сформованості готовності майбутніх учителів географії до професійної діяльності; вивчення стану викладання спеціальних і психолого-педагогічних дисциплін 3 урахуванням вимог формування відповідної готовності; контроль успішності засвоєння системи знань, умінь і навичок майбутніми вчителями географії; моніторинг успішності проходження майбутніми вчителями географії виробничих практик в умовах профільного навчання.

Такий контроль може здійснюватися ректоратом, дирекцією, деканатами, відділеннями, кафедрами, методичними та адміністративними комісіями. Він має грунтуватися на правовій основі та охоплювати насамперед стан навчальнометодичного забезпечення, лабораторну базу, кадровий склад, організацію навчального процесу (розклад занять, ведення поточної документації, рівень викладання дисциплін відповідно до вимог, позааудиторну роботу тощо).

Технологічна частина системного моніторингу та контролю передбачає такі методи та засоби оцінювання: вивчення документів і результатів навчально-виховної діяльності студентів і викладачів; проведення зрізових контрольних робіт; спостереження; опитування (усне та письмове); тестування; експертні оцінки.

Завершальним етапом системного моніторингу та контролю має бути узагальнення отриманих даних, опис результатів, обговорення їх на науковометодичних семінарах, нарадах, визначення майбутніх перспектив.

Отже, реалізація цієї умови забезпечує створення об'єктивної аналітичної бази 
для управління процесом формування готовності майбутніх учителів географії до профільного навчання старшокласників, забезпечує його якість, гнучкість, цілеспрямованість та створює передумови підвищення рівня означеної готовності у студентів, майбутніх фахівців.

Водночас необхідно зауважити, що окремі аспекти цієї важливої проблеми ще потребують вивчення. Аналіз практики показує, що нині у вищих навчальних закладах організовується й проводиться моніторинг в основному якості навчальновиховного процесу й результатів (працевлаштування випускників тощо). На жаль, майже відсутні моніторингові дослідження умов організації діяльності вищого навчального закладу, немає досліджень, об'єктом яких $\epsilon$ рівень управління навчальним закладом, якість ресурсів, інформаційно-освітнього середовища тощо.

Поза увагою під час організації моніторингу якості освіти залишається дослідження зовнішніх упливів на діяльність вищого навчального закладу: аналіз ринку праці, освітні потреби учасників навчально-виховного процесу, розвиток системи освітніх послуг.

На рівні навчального закладу не досліджуються такі питання, як відстеження ефективності напрямів стратегічного розвитку навчального закладу, систематичність та грунтовність налагодження зовнішніх і внутрішніх зв'язків із соціальними установами, відстеження політики якості й стратегії розвитку навчального закладу, розвиток кадрової політики (безперервність навчання педагогічних працівників), управління фінансовими, матеріальними ресурсами, іміджеві аспекти діяльності навчального закладу. I головне, на наш погляд, це те, що немає цілеспрямованого, безперервного відстеження професійно важливих особистісних характеристик, що детермінують професійне становлення студента, а також параметри оцінювання їх професійного розвитку.

\section{Література}

1. Сльникова Г. В. Наукові основи розвитку управління загальною середньою освітою в регіоні : [монографія] / Г. В. Єльникова. - К. : ДАККО, 1999. - 303 с. 2. Майоров А. Н. Мониторинг в системе информационного обеспечения управления образованием : автореф. дис. на соискание уч. степени докт. пед. наук.: спец. 13.00.01. «Общая педагогика. История педагогики и образования» / А. Н. Майоров. - СанктПетербург, 2003. - 45 с. 3. Моніторинг якості освіти: становлення та розвиток в Україні: Рекомендації з освітньої політики / за заг. ред. О. І. Локшиної. - К. : К.І.С., 2004. - 160 с. 4. Чандра М. Ю. Системный мониторинг как средство управления качеством образовательного процесса: дис. ... канд. пед. наук: 13.00.08/ Чандра Маргарита Юрьевна. - Волгоград, 2008. - 203 с.

УДК $316.61: 37.03$

Світлана Матвійчина

\section{ФОРМУВАННЯ ІНТЕРАКТИВНОГО СОЦІОКУЛЬТУРНОГО СЕРЕДОВИЩА ЯК ДИДАКТИЧНА УМОВА САМОРОЗВИТКУ ОСОБИСТОСТІ СТУДЕНТІВ КОЛЕДЖІВ}

Матвійчина С. В. Формування інтерактивного соціокультурного середовища як дидактична умова саморозвитку особистості студентів коледжів.

Статтю присвячено дослідженню сутності наукових категорій «соціокультурне середовище» та «інтерактивне соціокультурне середовище». Проаналізовано основні підходи до змісту зазначених наукових дефініцій. Здійснено аналіз їх сутності з точки зору психології та педагогіки. Основну увагу зосереджено на аналізі підходів науковців до змісту, який вони вкладають у трактування інтерактивного соціокультурного середовища як вагомої дидактичної умови, що суттєво впливає на 